\title{
Foreword
}

\section{Educational Entrepreneurship in a Changing America}

\author{
Mitchell L.Stevens
}

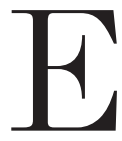

ducation policies enacted by state and federal governments between 1944 and 1980 transformed the U.S. national class structure. The end of World War II created new challenges for an overnight superpower: to reabsorb and reward returning veterans, to retool a wartime economy for consumer markets, to create a specifically American version of an enlightened modern society, and to assert U.S. dominance in global military, diplomatic, and cultural affairs. Historians have now amply demonstrated that national leaders addressed all of these problems in part by dramatically expanding the provision of postsecondary credentials. The Servicemen's Readjustment Act (1944), the National Education Defense Act (1958), the California Master Plan for Higher Education (1960), and the Higher Education Act (1965) are among the many policies that effectively underwrote the creation of the market for college degrees that now does so much to organize the distribution of opportunity in the United States.

Randall Collins's Credential Society does not address this pivotal period. Instead, it investigates the evolution of credentialism throughout the long arc of U.S. state-building between the founding of the Republic and World War I, during which influential people worked across many generations to build a system of opportunity allocation that might be broadly respected and sustained in 
a culturally plural, geographically dispersed, and horizontally federated polity.

The book is a masterpiece of sociological synthesis. In a nutshell, it argues that school-founding was an appealing means through which religious zealots, businesspeople, and elected leaders could cooperate to build economic and civic capacity on a steadily advancing Western frontier. Schools were the organizational infrastructure whose general value elicited consensus from otherwise divided groups: ethnic and religious factions, rival cities and regions, and those with very different views about the proper size and reach of the state. Schools were multipurpose institutions, good for redeeming souls, growing human capital, boosting real estate values, eliciting philanthropic donations, and marking occupational boundaries all at once. The work was carried out by actors Collins aptly dubbed "educational entrepreneurs": people who pursued the aggrandizement of their own varied purposes by building schools.

The Credential Society argued that by the early twentieth century Americans had developed an indigenous system for adjudicating difference and hierarchy on the basis of educational attainment and completion. Over time the leaders of this officially egalitarian nation came to agree that the amount, kind, and brand of schooling obtained by individuals and groups was a generally legitimate means of partitioning resources and prestige. If, as in all societies, Americans would continually struggle over the allocation of advantage, they would do so largely through disputes over access to schooling and the formal credentials schools conferred.

Collins crafted his account at the height of the Cold War, when the United States was a mature nation-state with only one real rival for dominance on the world stage. During the same years that The Credential Society was being written, the four-year college degree became the sine qua non of middle-class respectability and whitecollar employability in the United States. Only now, and through a rearview mirror, is it possible to fully see the reciprocal implication of credentialism and massive government investment in higher education in the middle of the twentieth century. 
In the decades after the release of the book's first edition, the political economy of college and credentials kept on changing. The close of the Cold War also meant the end of unquestioned federal government support for academic research. The property tax revolt that began in California in the I970s spread nationwide, riding on white voters' resentments about the redistributive effects of Cold War social welfare expenditures and whites' mounting anxiety about their own economic security. The revolt ultimately restricted the ability of legislatures to raise taxes for public services and infrastructure, including higher education.

Ongoing advances in travel and communications technology reduced the friction of distance that had long obliged colleges and universities to seek clients from within their own regions. Ambitious schools within easy driving distance of major airports increasingly sought academically accomplished students from all over the nation and the world. Photogenic campuses, top-ranked sports teams, and comfortable residential amenities became even more important for recruiting the most coveted students: those with strong academic records who also had families affluent enough to pay full tuition. Titularly public flagship research universities were among the most entrepreneurial recruiters because they needed tuition revenue to compensate for diminished subsidies from state legislatures.

Entrepreneurship of a different sort continued apace at the lower end of the national academic prestige system. Schools organized as for-profit businesses had long served niche markets, specifically in the skilled trades, but by the early 2000 s this sector was growing briskly. For-profit entrepreneurs recognized an opportunity among the millions of adults seeking occupational mobility but who were poorly served by cash-strapped community colleges and comprehensive universities oriented to recruiting teenagers. Even as they reduced direct institutional subsidies, federal and state governments continued to underwrite tuition grants and loans, buoying the consumer market for even the least prestigious college degrees. Some for-profit schools became publicly traded companies and, 
thanks to canny marketing campaigns and minimal government oversight, reaped eye-popping revenues. The bubble burst during the financial crisis of 2008 , but the for-profit sector successfully resisted any serious regulatory encroachment. For-profits even attracted fresh forms of patronage from self-styled "entrepreneurial" philanthropies, whose program officers make no presumption that elite universities and their tenured eggheads should necessarily shape the future of higher education. Organizations like the Strada Education Network-novel hybrids of educational charities and venture capital firms-now pour millions of dollars into the postsecondary sector each year.

Throughout this history, the basic social conflicts that drove Collins's germinal narrative continue to be in play: high levels of material inequality; weak government oversight; an exceptionally variegated class culture that recognizes plural-we now call them "diverse"-ideals of merit; and an economic culture that embraces iconoclasm, risk-taking, and school-founding all at once. Since the initial release of The Credential Society, the role of educational degrees in certifying human worth and distributing social opportunity has only become more central to the overall organization of American life.

In his own preface to this new edition, Collins predicts growing vertical stratification of credentials in the future. He anticipates an ever-upward ratcheting of the formal degrees required for the most coveted occupational positions and greater expenditures by the most affluent families in competitive academic selection games. I do not dispute this prediction - and plenty of good empirical evidence supports it-but I would add three new phenomena animating contemporary education politics that classical credentialing theory did not, perhaps could not, predict.

First is the spectacular profusion of new kinds of academic assets. I am referring here to massive open online course (MOOC) completion certificates and online degree programs and badges of every description, and also to the digital platforms, most prominently but not exclusively LinkedIn, that make them visible to the world. 
Neither the legal status nor the exchange value of these assets has yet fully coalesced, but they are rapidly accumulating public attention and innovative consideration by respectable universities. Digital mediation and related sociotechnological innovations such as blockchains make it possible to imagine a future in which the verification of a wide array of credentials might occur fully independent of governments and schools, creating conditions for credential markets that transcend accreditation cartels and national laws. Technological affordances cannot predict their own utilization, but they do change the risks, costs, and potential payoffs of educational entrepreneurship.

Second, the massification of college access has created a new class cleavage all its own. As Collins deftly explained, attainment of a four-year degree is a rite of passage into middle-class respectability. It also has become its own hot line of social conflict, distinguishing those who imagine themselves to be true, if neglected, American workers and patriots, and those who see themselves as the rightful benefactors of economic progress and enlightened government policy. The first group's definition of reality, with its skepticism of science and cosmopolitanism and fancy degrees, now has a primacy in national discourse not seen in the United States for two hundred years. Whether and how the institutional infrastructure of class and credentials built during the second half of the twentieth century survives this great tide of populist resentment toward its top beneficiaries remains to be seen.

Third, the cost of the credential society is now substantially shouldered by everyday citizens. When Collins was writing this book in the 1970s, governments were the primary patrons of educational credentials. In addition to its subsidy of high school diplomas via universal mass schooling, government built the market for postsecondary credentials. Serial omnibus acts of Congress designated billions of dollars for college tuition and put it in citizens' pocketbooks. State taxes built the schools to absorb the subsidized demand for college degrees. Loan programs, often administered by private firms but cushioned by government guarantees that favored lenders, 
allowed colleges to steadily raise fees while deferring the pain of repayment into the future. Academic social scientists abetted the process by promising citizens and policy makers that education loans are "good" debt—worthy investments in social mobility—except when they aren't.

Most of the benefits of college educations accrue to those who finish at least four-year degrees. About half of those who enter college seeking such degrees fail to earn them in a timely fashion. Americans now owe more on education loans than they do on their credit cards, and a debt-free BA has become a transparent mark of class privilege-not merit. It is not clear how far our civic fabric can stretch to accommodate these facts without tearing. 


\section{The Credential Society}


